\title{
First record of albinism in gafftopsail catfish Bagre marinus (Pisces: Ariidae) from southeast Mexico
}

\author{
Primer registro de albinismo en el bagre bandera Bagre marinus \\ (Pisces: Ariidae) del sureste de México
}

\section{Armando T. Wakida-Kusunoki ${ }^{1}$ and Luis Enrique Amador-del-Ángel ${ }^{2}$}

\begin{abstract}
${ }^{1}$ Instituto Nacional de Pesca, Centro Regional de Investigación Pesquera de Ciudad del Carmen, Av. Héroes del 21 de Abril s/ n, Col. Playa Norte, C.P. 24120, Ciudad del Carmen, Campeche, México. armandowakida@yahoo.com.mx

${ }^{2}$ Universidad Autónoma del Carmen, Centro de Investigación de Ciencias Ambientales (CICA), Av. Laguna de Términos s/n Col. Renovación 2da Sección, C.P. 24155, Ciudad del Carmen, Campeche, México. leamador@yahoo.com

Abstract. This paper describes the first record of albinism in the gafftopsail catfish, Bagre marinus, on the coast of Tabasco, Mexico. The standard length of the albino specimen was $311 \mathrm{~mm}$ and the gutted weight was $962 \mathrm{~g}$. It is not only the first record of albinism of the Bagre genus, but of any kind of fish in the southeastern Gulf of Mexico.
\end{abstract}

Key words: Abnormalities, pigmentation, Tabasco

\section{INTRODUCTION}

Albinism is a genetically inherited condition in which the pigment protein melanin is either absent or nonfunctional (Reum et al. 2008). There are 2 kinds of albinism: (1) complete albinism, where the integumentary and retinal pigmentation is absent and (2), partial albinism or leucism, where there is a partial or complete loss of integumentary pigments, but the retinal pigments are present (Goto et al. 2004). In most fish, the absence of color is related to mutations in the genes of the tyrosinase family, where the skin of albinos lacks melanin and eye development is affected (Wang et al. 2007).

Total or partial albinism has been observed in 36 different species of cartilaginous fish, including skates, rays and sharks (Sandoval-Castillo et al. 2006, Veena et al. 2011) with different anatomical and ecological features, demonstrating that albinism is not exclusive to some ecological or taxonomic groups. Albinism has also been reported in more than 20 species of teleosts worldwide (e.g., Sazima \& Pombal Jr. 1986, Béarez 2002, Brito \& Caramaschi 2005, Reum et al. 2008, Mansur 2011, Piorski \& Nunes 2011).

The gafftopsail catfish Bagre marinus (Mitchill, 1815) is a tropical benthic fish distributed in coastal waters from Cape Cod, Massachusetts to Panama, and throughout the Gulf of Mexico coast (Muncy \& Wingo 1983). It is mainly marine but enters brackish estuaries with relatively high salinities (Cervigón et al. 1992). B. marinus is one of the most important fisheries in the Southeastern coastal zone of the Gulf of Mexico, particularly along the coast of
Tabasco state, where it is captured abundantly almost all year round (Mendoza-Carranza \& Hernández-Franyutti 2005).

This paper describes the first record of albinism in the gafftopsail catfish, Bagre marinus, on the coast of Tabasco, Mexico.

\section{Materials AND METHODS}

An albino adult female B. marinus was landed in July 2012 from the commercial catch of the small-scale daytime fleet from San Pedro, Tabasco, in the Southern Gulf of Mexico (18³9'32.35" N, 92²8'13.45"W). Bottom-set longlines with $60 \mathrm{~mm}$ shank length tuna circle hooks were the method of capture. The catch depth ranged from 10 to $40 \mathrm{~m}$. The specimen was collected and transported to the laboratory where it was identified using the criteria described by Hoese \& Moore (1998). The specimen was deposited in the Ichthyology Collection of the Centro de Investigación de Ciencias Ambientales (CICA) of the Universidad Autónoma del Carmen under catalog number CI-CICA-UNACAR 0250.

\section{Results AND DisCussion}

The standard length of the albino specimen was $311 \mathrm{~mm}$ and the gutted weight was $962 \mathrm{~g}$. The entire fish including the fins was dull whitish pink in color and devoid of any pigmentation (Fig. 1a). Pigmented specimens of $B$. marinus normally have a blue-grey to dark brown color 


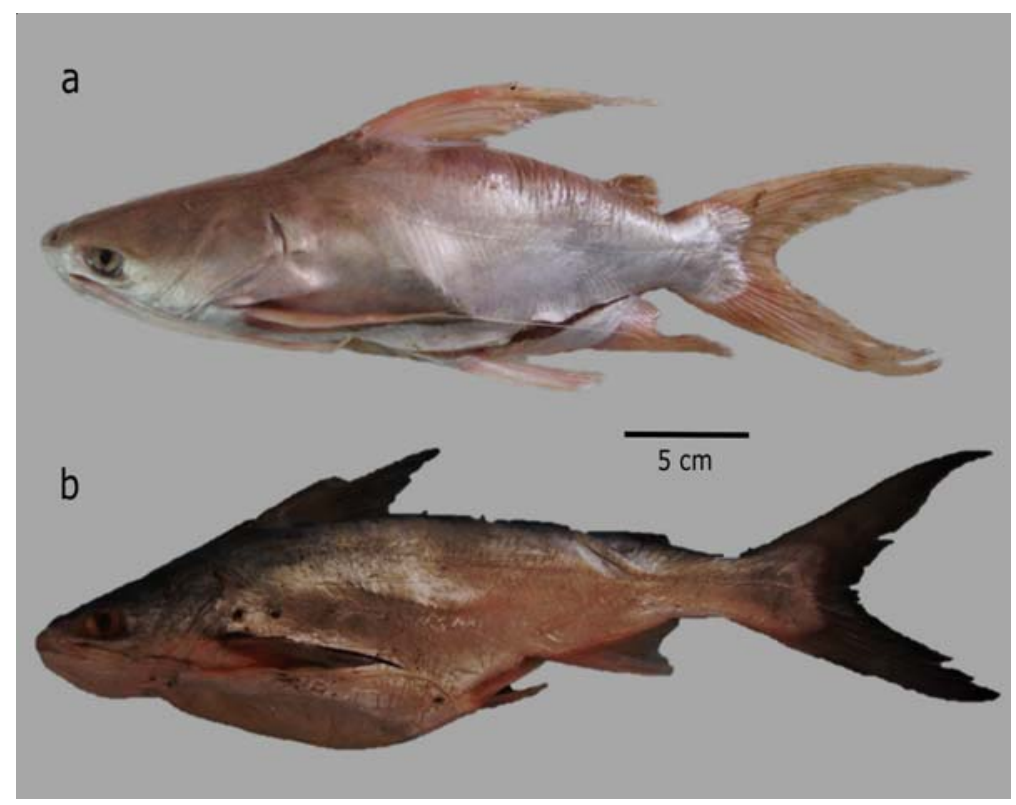

Figure 1. Lateral view of the gafftopsail catfish, Bagre marinus. a) Albino specimen and b) normal specimen. Photographs were taken from fresh fish. by A.T. WakidaKusunoki / Vista lateral del bagre bandera Bagre marinus. a) espécimen albino y b) espécimen normal. (Fotografía tomada en ejemplares frescos por A.T. WakidaKusunoki)

Table 1. Albinism reports in Order Siluriformes / Reportes de albinismo en el Orden Siluriformes

\begin{tabular}{|c|c|c|}
\hline Family & Species & Reference \\
\hline \multirow[t]{6}{*}{ Ariidae } & Arius jella $($ Day, 1877$)$ & Gupta \& Bhowmik 1958 \\
\hline & Plicofollis dussumieri (Valenciennes, 1840) & Rajapandian. \& Sundaram 1967 \\
\hline & Plicofollis tenuispinis (Day, 1877) & Baragi et al. 1975 \\
\hline & Nemapteryx caelata (Valenciennes, 1840) & Krishna \& Somvanshi 1979, Das et al. 2006 \\
\hline & Osteogeneiosus militaris (Linnaeus, 1758) & Chavan et al. 2008 \\
\hline & Bagre marinus (Mitchill, 1815) & Present work \\
\hline \multirow[t]{4}{*}{ Ictaluridae } & Ictalurus punctatus (Rafinesque, 1818) & Aitken 1937, Menzel 1944 \\
\hline & Ameiurus catus (Linnaeus, 1758) & Mclane 1950, Britton \& Davies 2006 \\
\hline & Noturus gyrinus (Mitchill, 1817) & Holder \& Ramsey 1972 \\
\hline & Noturus flavus (Rafinesque, 1818) & Platania et al. 1986 \\
\hline Loricariidae & Schizolecis guntheri (Miranda Ribeiro, 1918) & Brito \& Caramaschi 2005 \\
\hline \multirow[t]{2}{*}{ Pimelodidae } & Zungaro zungaro (Humboldt, 1821) & Taberner et al. 1976 \\
\hline & Rhamdella minuta (Lutken, 1875) & Sazima \& Pombal Jr 1986 \\
\hline Siluridae & Silurus glanis (Linnaeus, 1758) & Platania et al. 1986, Dingerkus et al. 1991 \\
\hline
\end{tabular}


with dark margins on the dorsal part of the body and caudal fin, and a light grey belly; the ventral body surface is unpigmented (Fig. 1b).

Several cases of albinism have been reported in catfish (Table 1), but until now no record of an albino gafftopsail catfish has been reported.

The incidence of albinism can be artificially increased in fish by exposing the eggs to heavy metals (e.g., arsenic, cadmium, copper, mercury, selenium, zinc) (Oliveira \& Foresti 1996). Thus, the albinism in B. marinus is more probably the result of a genetic random alteration since high concentrations of heavy metals seem to be improbable in the sampled habitat.

Sazima \& Pombal Jr. (1986) and Brito \& Caramaschi (2005) stated that albinism in tropical fish is more common among nocturnal and/or cryptobiotic species than among diurnal or non-cryptobiotic ones.

The lack of coloration in albinos has been suggested to increase susceptibility to predation or render them less attractive for reproduction (Sandoval-Castillo et al. 2006), however, the considerable size of adult albino gafftopsail catfish in question, leads us to suppose that albinism in catfish is not determinant for the survival of the organism.

This is the first report of albinism in the genus Bagre and in all fish from the southeastern Gulf of Mexico. $B$. marinus is a species subject to commercial fishing with a high number of individuals being captured for decades with no previous record of albinism. This, then, is a rare event still undetected in most wild fish species, at least regarding adult individuals.

\section{ACKNOWLEDGMents}

We would like to extend our thanks to Fernando Wakida, Universidad Autónoma de Baja California for his useful suggestions regarding the manuscript.

\section{LITERATURE CITED}

Aitken WW. 1937. Albinism in Ictalurus punctatus. Copeia 1937(1): 64.

Baragi VM, RB Yaragal \& PSBR James. 1976. On an albino of the marine cat fish, Tachysurus tenuispinis (Day). Matsya 2: 82-83.

Béarez P. 2002. First record of albinism in a moray eel, Muraena clepsydra (Muraenidae) from Ecuador. Cybium 26(2): 159160.
Brito MFG \& EP Caramaschi. 2005. An albino armored catfish Schizolecis guntheri (Siluriformes: Loricariidae) from an Atlantic forest coastal basin. Neotropical Ichthyology 3: 123-125.

Britton JR \& GD Davies. 2006. First record of the white catfish Ameiurus catus in Great Britain. Journal of Fish Biology 69(4): 1236-1238.

Cervigón F, R Cipriani, W Fischer, L Garibaldi, M Hendrickx, AJ Lemus, R Márquez, JM Poutiers, G Robaina \& B Rodriguez. 1992. Fichas FAO de identificación de especies para los fines de la pesca. Guía de campo de las especies comerciales marinas y de aguas salobres de la costa septentrional de Sur América, 513 pp. FAO, Roma.

Chavan BB, S Sundaram, AD Sawant \& T Das. 2008. Record of complete albinism in marine catfish, Osteogeneiosus militaris (Linnaeus, 1758), landed at Mumbai. Marine Fisheries Information Service Technical and Extension Series 197: 15-17.

Das T, BB Chavan \& S Sundaram. 2006. A rare record of albino catfish, Arius caelaltus landed at Mumbai. Marine Fisheries Information Service Technical and Extension Series 188: 21-22.

Dingerkus G, B Seret \& E Guilbert. 1991. The first albino Wels, Silurus glanis Linnaeus, 1758, from France, with a review of albinism in catfishes (Teleostei: Siluriformes). Cybium 15: 185-188.

Goto M, K Sato-Matsumura, D Sawamura, K Yolota, $\mathbf{H}$ Nakamura \& H Shimiz. 2004. Tyrosinase gene analysis in Japanese patients with oculocutaneous albinism. Journal of Dermatological Science 35: 215-220.

Gupta PD \& RM Bhowmik. 1958. A case of albinism in Arius jella Day from India. Science \& Culture 24(6): 283.

Holder DR \& JS Ramsey. 1972. A case of albinism in the tadpole madtom, Noturus gyrinus Transactions of the American Fisheries Society 101(3): 566-567.

Hoese HD \& RH Moore. 1998. Fishes of the Gulf of Mexico: Texas, Louisiana, and adjacent waters, 327 pp. Texas A \& M University Press, College Station.

Krishna-Pillai S \& VS Somvanshi. 1979. A case of complete albinism in marine cat fish Arius caelatus (Valenciennes). Indian Journal of Fisheries 26(1/2): 240-241.

Mansur L. 2011. First record of partial albinism in the temperate rocky reefs fish Acanthistius patachonicus (Insertae sedis) off Southwestern Atlantic Ocean. Pan-American Journal of Aquatic Science 6(2): 185-187.

McLane WM. 1950. An albinistic lctalurus catus from Florida. Copeia 1950(2): 149. 
Mendoza-Carranza M \& A Hernández-Franyutti. 2005. Annual reproductive cycle of gafftopsail catfish, Bagre marinus (Ariidae) in a tropical coastal environment in the Gulf of Mexico. Hidrobiológica 15(3): 275-282.

Menzel RW. 1944. Albino catfish in Virginia. Copeia 1944(2): 124.

Muncy RJ \& WM Wingo. 1983. Species profiles: life histories and environmental requirements of coastal fishes and invertebrates (Gulf of Mexico) - sea catfish and gafftopsail catfish. U.S. Fish and Wildlife Service, Division of Biological Services, FWS/OBS-82/11.5. U.S. Army Corps of Engineers, TREL-82-4: 1-17.

Oliveira C \& F Foresti. 1996. Albinism in the banded knifefish, Gymnotus carapo. Tropical Fish Hobbyist 44(12): 92-96.

Piorski NM \& JLS Nunes. 2011. A case in albinism in Batrachoides surinamensis (Batrachoidiformes: Batrachoididae) from northeastern Brazil. Marine Biodiversity Records 3: e99.

Platania SP, TR Cummings \& KJ Kehmeier. 1986. First verified record of the stonecat, Noturus flavus (Ictaluridae), in the South Platte River System, Colorado, with notes on an albinistic specimen. The Southwestern Naturalist 31(4): 553-555.

Rajapandian ME \& KS Sundaram. 1967. A case of complete albinism in the marine cat fish Tachysurus dussumieri (Cuvier and Valenciennes). Journal of Marine Biological Association of India 9(1): 194-195.
Reum JCP, CE Paulsen, TW Pietsch \& SL Parker-Stetter. 2008. First record of an albino chimaeriform fish, Hydrolagus colliei. Northwestern Naturalist 89: 60-62.

Sandoval-Castillo J, E Mariano-Melendez \& C Villavicencio-Garayzar. 2006. New records of albinism in two elasmobranchs: the tiger shark Galeocerdo cuvier and the giant electric ray Narcine entemedor. Cybium 30(2): 191-192.

Sazima I \& J Pombal Jr. 1986. Um albino de Rhamdella minuta, com notas sobre comportamento (Osteichthyes, Pimelodidae). Revista Brasileira de Biologia 46: 377-381.

Taberner R, JO Fernández-Santos \& JO Castelli. 1976. Un «manguruyú» albino Paulicea luetkeni (Steindachner 1876) Eigenmann 1910. Physis B 35(91): 121-123.

Veena SST, SG Raje \& R Durgekar. 2011. Case of leucism in the spadenose shark, Scoliodon laticaudus (Müller and Henle, 1838) from Mangalore, Karnataka. Indian Journal of Fisheries 58(1): 109-112.

Wang J, L Hou, R Zhang, X Zhao, L Jiang, W Sun, J An \& $X$ Li. 2007. The tyrosinase gene family and albinism in fish. Chinese Journal of Oceanology and Limnology 25(2): 191-198.

Received 13 August 2012 and accepted 10 December 2012

Associate Editor: Gabriela Muñoz C. 